\title{
Artigo Original / Original Paper \\ Edmundoa, Neoregelia e Wittrockia (Bromeliaceae: Bromelioideae) no Parque Nacional da Serra dos Órgãos, Rio de Janeiro, Brasil
}

\author{
Edmundoa, Neoregelia and Wittrockia (Bromeliaceae: Bromelioideae) \\ in Serra dos Órgãos National Park, Rio de Janeiro, Brazil
}

\author{
Igor Musauer Kessous ${ }^{1,3}$, Dayvid Rodrigues Couto ${ }^{1}$, Bruno Paixão Souza ${ }^{1}$, Ricardo Loyola de Moura ${ }^{2}$ \\ \& Andrea Ferreira da Costa $^{2}$
}

\begin{abstract}
Resumo
O Parque Nacional da Serra dos Órgãos (PARNASO) localiza-se na região serrana do estado do Rio de Janeiro e representa uma importante unidade de conservação brasileira, guardando importantes ecossistemas da Mata Atlântica do sudeste do Brasil. Apresenta-se um estudo florístico-taxonômico dos gêneros Edmundoa, Neoregelia e Wittrockia (Bromeliaceae, Bromelioideae) no PARNASO, baseado em coletas de campo, materiais de herbário e bibliografia. Descrições foram feitas com base na variação morfológica observada em todos os exemplares provenientes da região. Foram encontrados 16 táxons, sendo Neoregelia o gênero mais rico, com 13 espécies, seguidos por Wittrockia (duas) e Edmundoa (uma), nenhum incluído em listas oficiais de espécies ameaçadas. No presente artigo são apresentadas chaves de identificação, descrições, informações sobre distribuição geográfica e comentários morfológicos e taxonômicos para os táxons.
\end{abstract}

Palavras-chave: conservação, Mata Atlântica, nidularióide, PARNASO, taxonomia.

\begin{abstract}
The Serra dos Órgãos National Park (PARNASO) is located in montane region of Rio de Janeiro state and is an important Brazilian protected area, preserving important ecosystems of the Atlantic Forest of southeastern Brazil. Here we present a taxonomic study of the genera Edmundoa, Neoregelia and Wittrockia (Bromeliaceae, Bromelioideae) in PARNASO, based on field collections, herbarium material and bibliography. Descriptions were made based on the morphological variations observed in all specimens from the region. Sixteen taxa were found, being Neoregelia the richest genus with 13 species, followed by Wittrockia (two) and Edmundoa (one), none of them is included in official lists of endangered species. Identification keys, descriptions, information on geographic distribution and morphological and taxonomical comments for taxa are presented. Key words: conservation, Atlantic Rain Forest, nidularioid, PARNASO, taxonomy.
\end{abstract}

\section{Introdução}

O domínio fitogeográfico da Mata Atlântica apresenta elevados níveis de riqueza e endemismo e abriga ca. 15.592 espécies, distribuídas em 2.070 gêneros de angiospermas (BFG 2018), dos quais, ca. $6 \%$ dos gêneros e $45 \%$ das espécies são endêmicas deste domínio (Stehmann et al. 2009). Esta expressiva riqueza e endemismo da Mata Atlântica, associados à devastação sofrida em tempos pretéritos, incluíram este Domínio como um dos 34 hotspots de biodiversidade global (Mittermeier et al. 2004).

Bromeliaceae A. Juss., é uma família monofilética (Gaut et al. 1992; Duvall et al. 1993; Chase et al. 2000; Bouchenak-Khelladi et al. 2014; APG IV 2016) que inclui cerca de 3.600 espécies, distribuídas em 75 gêneros (Gouda et al., continuamente atualizado), representando um dos

\footnotetext{
${ }^{1}$ Universidade Federal do Rio de Janeiro, Prog. Pós-graduação em Ciências Biológicas (Botânica), Depto. Botânica, Quinta da Boa Vista, Horto Botânico, 20940-040, Rio de Janeiro, RJ, Brasil.

${ }^{2}$ Universidade Federal do Rio de Janeiro, Museu Nacional, Depto. Botânica, Quinta da Boa Vista, Horto Botânico, 20940-040, Rio de Janeiro, RJ, Brasil.

${ }^{3}$ Autor para correspondência: igor.kessous@gmail.com
} 
mais expressivos componentes florísticos da região neotropical. Neste contexto, o Domínio da Mata Atlântica é reconhecido como um dos principais centros de diversidade de gêneros e espécies da família (Martinelli et al. 2008), e para o qual foram registradas 915 espécies (BFG 2018).

Atualmente, são reconhecidas oito subfamílias (Givnish et al. 2007, 2011), entre as quais os maiores problemas de delimitação genérica são observados em Bromelioideae, cujos conceitos taxonômicos são divergentes entre os diferentes tratamentos (e.g., Baker 1889; Mez 1896, 1934-5; Smith \& Downs 1979). A subfamília Bromelioideae é monofilética (Terry et al. 1997; Horres et al. 2000; Schulte et al. 2005; Horres et al. 2007; Givinish et al. 2007; Schulte et al. 2009; Sass \& Specht 2010; Givinish et al. 2011) e reúne ca. 800 espécies distribuídas em 33 gêneros (Luther 2012), sendo a segunda maior subfamília de Bromeliaceae. Possui a diversificação mais tardia entre as demais e está associada ao "Clado do Escudo Brasileiro" (Givinish et al. 2007, 2011) tendo seu centro de diversidade na Mata Atlântica (Martinelli et al. 2008).

A subfamília Bromelioideae apresenta um grupo de gêneros que possui as inflorescências congestas, geralmente embutidas nas rosetas foliares, semelhantes àquelas encontradas no gênero Nidularium (Leme 1997, 1998). Este grupo de gêneros é chamado "complexo nidularióide" e inclui também Neoregelia L.B.Sm., Wittrockia Lindm., Edmundoa Leme, Canistrum É. Morren, Canistropsis (Mez) Leme, Eduandrea Leme, W. Till, G.K. Br., J.R. Grant \& Govaerts e algumas espécies de Aechmea Ruiz \& Pav., os quais, juntos, somam cerca de 187 espécies (Luther 2012), cuja maior diversidade é encontrada no Domínio Atlântico (Martinelli et al. 2008). Análises filogenéticas baseadas em marcadores moleculares apontaram Nidularium e Edmundoa como monofiléticos, no entanto o posicionamento de Neoregelia, Canistrum e Wittrockia permanece incerto (Brown \& Leme 2000; Horres et al. 2007; Evans et al. 2015; Santos-Silva et al. 2017). A análise de Heller et al. (2015) baseada em AFLP, recuperou o grupo nidularióide incluindo Nidularium, Neoregelia, Canistropsis, Edmundoa e Wittrockia, os quais são caracterizados como epífitas facultativas da Mata Atlântica, na maioria das vezes com sépalas e pétalas esverdeadas ou esbranquiçadas e pólen biporado.

O Parque Nacional da Serra dos Órgãos (PARNASO) localiza-se na região serrana do estado do Rio de Janeiro e representa uma importante unidade de conservação brasileira, guardando importantes remanescentes da Mata Atlântica do Sudeste do Brasil. As Bromeliaceae estão representadas nesta unidade de conservação por cerca de 115 espécies dentre as quais 40 são pertencentes à subfamília Bromelioideae (Costa et al., dados não publicados). Aechmea e gêneros relacionados foram monografados por Neves et al. (2015) e parte dos nidularióides, Canistropsis e Nidularium, por Kessous \& Costa (2017). Desta forma, o presente artigo completa o tratamento florístico da subfamília no parque.

O objetivo deste estudo foi ampliar o conhecimento da flora do PARNASO, através do tratamento florístico-taxonômico dos gêneros Edmundoa, Neoregelia e Wittrockia presentes nesta unidade de conservação, realizar comentários sobre as espécies além de propor uma chave de identificação dos táxons. O presente trabalho é parte do Projeto Bromeliaceae Organensis desenvolvido no Laboratório de Sistemática de Bromeliaceae do Museu Nacional do Rio de Janeiro/ UFRJ e visa contribuir para ações de conservação da área em estudo.

\section{Material e Métodos}

Área de estudo

O Parque Nacional da Serra dos Órgãos (PARNASO) foi fundado em 1939, sendo o terceiro parque nacional mais antigo do país. A região localiza-se entre os municípios fluminenses de Guapimirim, Magé, Petrópolis e Teresópolis com uma área de cerca de 11.000 hectares. Possui um relevo montanhoso, apresentando um acentuado gradiente altitudinal, variando de 200 a 2.263 metros de altitude, e compreende a área mais escarpada e elevada de toda a Serra do Mar (Cronemberger \& Viveiros-de-Castro 2007).

A vegetação do PARNASO em sua maior extensão, é classificada como Floresta Ombrófila Densa, podendo ter diferentes formações conforme sua altitude: Formação Submontana (50-500 m), Formação montana (500-1.500 m), Formação alto-montana (1.500 m-) (IBGE 2012). Estima-se que em grande parte da área de aproximadamente 4.600 hectares ocorrem florestas em estado primário ou avançado de sucessão natural. Sua flora é caracterizada pelo predomínio de espécies lenhosas e presença marcante de epífitas vasculares. Nos campos altimontanos, encontrados em elevações acima de 1.800 metros (Rizzini 1979), desenvolvem-se platôs com extensões variáveis de rocha aflorada. Penhascos e picos 
rochosos são cobertos por arbustos inseridos em uma matriz de touceiras de gramíneas, com ervas esparsas e pteridófitas (Safford 1999; Safford \& Martinelli 2000).

\section{Levantamento bibliográfico} e coleta de dados

Para este estudo foram analisados espécimes depositados nos herbários $\mathrm{R}, \mathrm{RB}$ e $\mathrm{HB}$ além de consulta ao material digitalizado online dos herbários estrangeiros US, NY e M (Thiers, continuamente atualizado). Entre os anos de 2008 e 2016, foram coletados espécimes da família em diferentes áreas do parque no âmbito do Projeto Bromeliaceae organensis. O material coletado foi herborizado e acondicionado de acordo com a metodologia usual de trabalhos taxonômicos (Peixoto \& Maia 2013), e depositados no herbário R. Os espécimes coletados e aqueles analisados nos herbários consultados foram identificados e/ ou tiveram sua identificação conferida através da literatura especializada da família Bromeliaceae e do complexo nidularióide (e.g., Beer 1857; Mez 1892-4, 1896, 1934-5; Smith \& Downs 1979; Leme 1997, 1998, 2000). Publicações de novas espécies foram procuradas nas séries Luther \& Sieff (1994, 1997), Luther (2001), Luther \& Rabinowitz (2010) e Gouda et al. [continuamente atualizado] e através da Lista de espécies da Flora do Brasil e Flora do Brasil Online 2020 (BFG 2018).
As descrições foram feitas com base na variação morfológica observada nos exemplares provenientes da região. A terminologia descritiva segue Smith \& Downs (1977), Radford (1986), Scharf \& Gouda (2008) e Leme (1997, 1998, 2000). Características morfológicas perdidas no processo de herborização, como cores, posições e posturas foram retiradas das etiquetas dos espécimes analisados nos herbários ou da literatura. Na impossibilidade de observação de algumas estruturas, especialmente florais, as descrições foram complementadas através de Leme (1997, 1998 e 2000). As estruturas foram medidas nas porções mais largas e/ou mais longas. Dados de distribuição geográfica foram retirados da Lista de espécies da Flora do Brasil (BFG 2018) e complementadas por Martinelli et al. (2008, 2009). A classificação das formações vegetais e de altitudes segue IBGE (2012).

\section{Resultados e Discussão}

Foram registradas 16 espécies para o PARNASO, sendo treze de Neoregelia, duas de Wittrockia e uma de Edmundoa. Nenhuma das espécies está citada na lista oficial da flora ameaçada de extinção (MMA 2014). Por outro lado, este estudo apresenta o registro de 11 novas ocorrências para o PARNASO, de acordo com a lista apresentada no Plano de Manejo (ICMBio 2008). Entre estes, nove espécies de Neoregelia, uma de Edmundoa e uma de Wittrockia.

\section{Chave de identificação dos gêneros Edmundoa, Neoregelia e Wittrockia no Parque Nacional da Serra dos Órgãos}

1. Inflorescência com indumento lanuginoso denso castanho 1. Edmundoa

1'. Inflorescência glabra ou com indumento lepidoto.

2. Flores pediceladas. Inflorescência completamente embutida na roseta. Sépalas com ápice agudo ou obtuso 2. Neoregelia

2'. Flores sésseis. Inflorescência excedendo o comprimento da roseta. Sépalas com ápice acuminado 3. Wittrockia

\section{Edmundoa Leme.}

Edmundoa é um gênero monofilético com três espécies conhecidas (Leme 1997; SantosSilva et al. 2017). Foi descrito a partir de uma espécie de Canistrum por possuir indumento lanuginoso persistente como uma das suas principais características taxonômicas (Leme 1997). O gênero é endêmico da Mata Atlântica (Martinelli et al. 2008; BFG 2015), e no PARNASO é representado por uma variedade.
1.1. Edmundoa lindenii var. rosea (É. Morren) Leme, Canistrum - Bromélias da Mata Atlântica. 50. 1997.

Fig. $1 \mathrm{a}$

Planta terrícola, saxícola ou epífita, rizomatosa, ca. $60 \mathrm{~cm}$ alt. Folhas $16-40$, formando uma roseta infundibuliforme; bainha obovada, 15-23 × 9-17 cm, verde-alvacenta, indumento lepidoto denso em ambas as faces; lâmina linear, $10-78 \times 3,5-9 \mathrm{~cm}$, verde com máculas verdes mais escuras, levemente discolor, indumento 

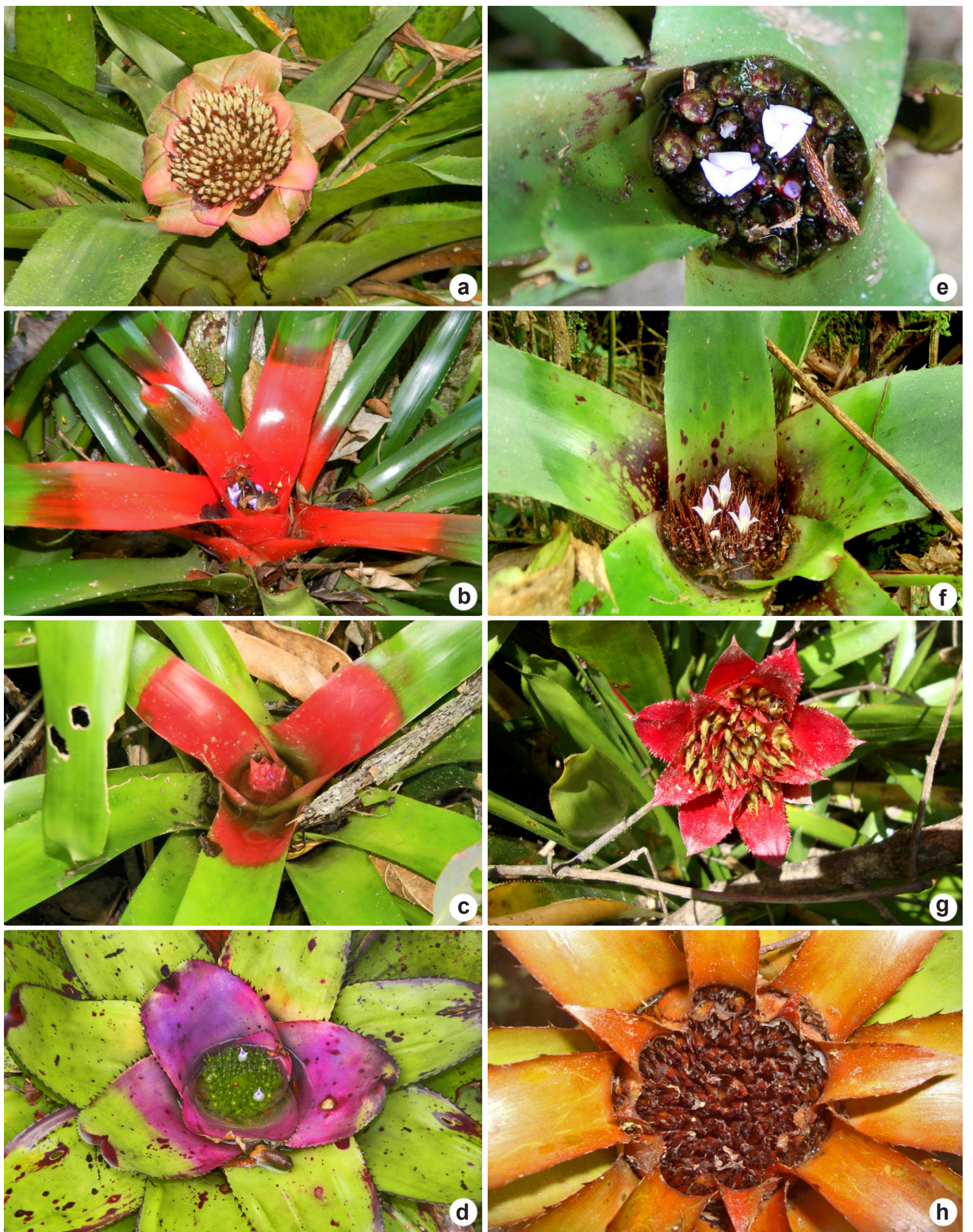

Figura 1 - a. Edmundoa lindenni; b. Neoregelia carolinae; c. Neoregelia compacta; d. Neoregelia concentrica; e. Neoregelia tristis; f. Neoregelia sp.; g. Wittrockia cyathiformis; h. Wittrockia gigantea. Fotos: Laboratório de Sistemática de Bromeliaceae MN-UFRJ.

Figure 1 - a. Edmundoa lindenni; b. Neoregelia carolinae; c. Neoregelia compacta; d. Neoregelia concentrica; e. Neoregelia tristis; f. Neoregelia sp.; g. Wittrockia cyathiformis; h. Wittrockia gigantea. Photos: Laboratório de Sistemática de Bromeliaceae MN-UFRJ. 
lepidoto esparso em ambas as faces, ápice obtuso, apiculado, margem serrilhada, acúleos ca. $2 \mathrm{~mm}$ compr., espaçados por 7-10 mm. Inflorescência 7-13 cm larg., composta, obcônico-capitada, com flores congestas; pedúnculo verde alvacento, com indumento lanuginoso castanho denso, 13-38 cm compr.; brácteas do pedúnculo $6-15 \mathrm{~cm}$ compr., elípticas a ovais, ápice agudo, com projeção apiculada, margem inteira, serrilhada em direção ao ápice no terço superior, róseo-alvacentas, indumento lepidoto em ambas as faces; fascículos de 7-10; brácteas primárias 5-9 cm compr., elípticas a ovais, ápice agudo, projeção apiculada ereta, margem serrilhada, róseas, indumento lepidoto esparso na face adaxial e lanuginoso denso na face abaxial. Brácteas Florais lineares a lanceoladas, 25-35 mm compr., ápice agudo, margem inteira, indumento lanuginoso castanho denso. Flores ca. 100, ca. 35 mm compr., sépalas elípticas, ligeiramente assimétricas, ca. $17 \mathrm{~mm}$ compr., concrescidas por 1-2 mm, ápice agudo, margem inteira, verdes, indumento lanuginoso em direção à base; pétalas estreitamente lanceoladoespatuladas, ca. $17 \mathrm{~mm}$ compr., concrescidas por ca. $2 \mathrm{~mm}$, verde-alvacentas, ápice obtuso, glabras; gineceu com ovário elipsoide. Frutos bacáceo, ca. $10 \mathrm{~mm}$ compr.

Material selecionado: Guapimirim, Sub-sede, próximo ao museu Martius, Parque Nacional da Serra dos Órgãos, 21.X.1977, fl. pass., Martinelli 3337 (RB); PARNASO, Vale do Rio Bananal, Condomínio Monte Olivete 2230'236"S, 43¹'54'"W, entre 450-550 m.s.m., 23.VIII.2009, fl. pass., Costa et al. 883 (R). Petrópolis, Serra da Estrela, leito da antiga estrada de ferro, meio da Serra, 29.III.1977, fl. pass., Martinelli 1570 (RB). Teresópolis, Parque Nacional da Serra dos Órgãos, sede, 7.IV.2011, fl. pass., Costa et al. 915 (R); 1952, fl. pass., Vidal II-1782 (R); estrada de dentro do PARNASO 22'26'57,2”S, 4259'10.2”'W, 9.V.2012, fl. pass., Kessous \& Pinto 7 (R).

Espécie endêmica do Sudeste e Sul do Brasil, ocorrendo na Floresta Ombrófila Densa e na Floresta Estacional Semi-decidual (Martinelli et al. 2008; Stehmann et al. 2009). Encontrada em Guapimirim, Petrópolis e Teresópolis na região de Floresta Pluvial Baixo-Montana e Floresta Pluvial Montana. O táxon se caracteriza principalmente por sua inflorescência excedendo a roseta, coloração de suas brácteas primárias róseas e a presença de indumento lanuginoso castanho denso na inflorescência. Esta última característica o diferencia dos demais nidularióides.

\section{Neoregelia L.B.Sm.}

O gênero Neoregelia possui 122 espécies (Gouda et al., continuamente atualizado), das quais 117 ocorrem no Brasil (BFG 2015). O gênero se divide em quatro subgêneros, Neoregelia subg. Neoregelia L.B.Sm., N. subg. Hylaeaicum (Ule) L.B.Sm., N. subg. Longipetalopsis Leme e $N$. subg. Protoregelia Till \& Leme. Neoregelia encontra-se entre os três mais diversos da família Bromeliaceae na Mata Atlântica, com 97 espécies e apresenta nesse domínio o seu principal centro de diversidade (Martinelli et al. 2008). No PARNASO é o segundo gênero mais diverso da família. As espécies apresentaram-se inseridas em dois subgêneros, $N$. subg. Longipetalopsis e $N$. subg. Neoregelia. $\mathrm{Na}$ área do parque, as espécies que se destacam com maior frequência de coletas são $N$. carolinae (Beer) L.B.Sm., N. tristis (Beer) L.B.Sm. e $N$. concentrica (Vell.) L.B.Sm., as quais formam grandes populações. A região da Serra da Estrela concentra a maior diversidade de espécies.

\section{Chave de identificação das espécies de Neoregelia no PARNASO}

1. Flores com até $55 \mathrm{~mm}$ compr. Neoregelia subg. Neoregelia.

2. Inflorescência composta; brácteas florais e do pedúnculo serrilhadas

2.10. Neoregelia lymaniana

2'. Inflorescência simples; brácteas florais e do pedúnculo inteiras.

3. Lâminas foliares internas com cor diferente das externas durante a floração.

4. Lâminas internas liláses-arroxeadas durante a floração; pedicelos $>15 \mathrm{~mm}$.

5. Lâminas com acúleos 3-5 mm compr.; pedicelo ca. $25 \mathrm{~mm}$ compr., brácteas florais lanceoladas..... 2.6. Neoregelia concentrica

5'. Lâminas com acúleos ca. 1,5 mm compr.; pedicelo ca. $17 \mathrm{~mm}$ compr., brácteas florais lineares 2.7. Neoregelia coriacea

4'. Lâminas internas vermelhas ou róseas durante a floração; pedicelos $<15 \mathrm{~mm}$. 
6. Lâminas com margem serrilhada; sépalas 20-24 mm, vermelhas ou róseas.....

6'. Lâminas com margem inteira; sépalas ca. $32 \mathrm{~mm}$, vermelho-róseas

2.4. Neoregelia carolinae

2.5. Neoregelia compacta

3'. Lâminas foliares internas com cor igual das externas durante a floração.

7. Lâminas no mesmo tom de verde.

8. Inflorescência ca. $1 \mathrm{~cm}$ larg.; pedúnculo ca. $13 \mathrm{~mm}$ compr.; pedicelo ca. $20 \mathrm{~mm}$

2.1. Neoregelia abendrothae

8'. Inflorescência ca. 3,5 cm larg.; pedúnculo ca. $60 \mathrm{~mm}$ compr.; pedicelo 3-4 mm

2.8. Neoregelia dungsiana

7'. Lâminas parcialmente verdes ou em diferentes tons de verde.

9. Lâminas verdes com ápice vermelho; bainha avermelhada; sépalas inteiramente verdes

2.11. Neoregelia macahensis

9'. Lâminas maculadas ou com listras purpúreas; bainha inteiramente ou com partes roxas; sépalas parcialmente verdes ou coloridas.

10. Plantas estoloníferas; bainha completamente roxa; inflorescência ca. 1,4 cm larg.; flores ca. $25 \mathrm{~mm}$; sépalas verdes com máculas purpúreas .....

2.2. Neoregelia ampullacea

10'. Plantas não estoloníferas, com rizomas; bainha colorida de roxo e verde; inflorescência de 5-7,5 cm de largura; flores $40-55 \mathrm{~mm}$; sépalas total ou parcialmente vináceas.

11. Bainha verde maculada de roxo; lâminas com até $2,5 \mathrm{~cm}$ de largura; inflorescência ca. 30 flores; pétalas ca. $21 \mathrm{~mm}$ 2.12. Neoregelia tristis

11'. Bainha roxa maculada de verde; lâminas mais largas que $4,5 \mathrm{~cm}$; inflorescência ca. 100 flores; pétalas ca. $40 \mathrm{~mm}$

2.13. Neoregelia sp.

1'. Flores maiores que $55 \mathrm{~mm}$. Neoregelia subg. Longipetalopsis.

12. Lâminas verdes com máculas brancas no ápice; acúleos $3-4 \mathrm{~mm}$; sépalas concrescidas por ca. 14 $\mathrm{mm}$; pétalas brancas arroxeadas no ápice 2.3. Neoregelia bragarum

12'. Lâminas verde-claras com manchas verde-escuras e roxas; acúleos ca. $1 \mathrm{~mm}$; sépalas concrescidas por ca. $2 \mathrm{~mm}$; pétalas inteiramente brancas 2.9. Neoregelia leucophoea

2.1. Neoregelia abendrothae L.B.Sm., Bull. Bromeliad Soc. 10: 24. 1960.

Planta epífita, estolonífera, ca. $20 \mathrm{~cm}$ alt. Folhas 6 a 10, dimórficas, suberetas ou eretas, formando uma roseta subcilíndrica; bainha elíptica, 3-11 × 1,5-4,5 cm, verde com máculas atropurpúreas na face adaxial, indumento lepidoto denso em ambas as faces; lâmina longo-atenuada (externas) e triangular-linear (internas), 16-65 $\times$ $0,6-4,5 \mathrm{~cm}$, verdes, indumento lepidoto esparso em ambas as faces, cartácea, ápice obtuso nas internas e longo apiculado nas externas, com projeção longo-apiculada, margem serrilhada, acúleos ca. $0,5 \mathrm{~mm}$ compr., espaçados por ca. $10 \mathrm{~mm}$, castanhos. Inflorescência ca. 1,1 cm larg., simples, umbeliforme, pedúnculo ca. $13 \mathrm{~mm}$ compr.; brácteas do pedúnculo ca. $15 \mathrm{~mm}$ compr., triangulares, ápice agudo, com pequena projeção apiculada, margem inteira, esbranquiçadas, cartáceas, indumento lepidoto esparso em ambas as faces. Brácteas Florais elípticas, ca. $20 \mathrm{~mm}$ compr., ápice agudo e apiculado, ereto, margem inteira, cartáceas, não carenadas, indumento lepidoto esparso. Flores ca. 10 , ca. $35 \mathrm{~mm}$ compr., pedicelo ca. $20 \mathrm{~mm}$ compr.; sépalas lanceoladas, assimétricas, ca. $14 \mathrm{~mm}$ compr., concrescidas por $1 \mathrm{~mm}$, ápice agudo, com projeção apiculada, ereto, verdes; pétalas ovais, ca. $20 \mathrm{~mm}$ compr., brancas, ápice agudo; androceu com anteras dorsifixas; gineceu com ovário obovoide. Frutos e sementes não vistos.

Material examinado: Teresópolis, 2.IV.1959, Abendroth 105 (US-Parátipo); 3.XII.1959, fl., Abendroth 119 (USHolótipo); Soberbo, estrada para Bahia, 15.VI.1968, Sucre 3215 (RB); Soberbo ca. $1.300 \mathrm{~m}$ de altitude, 16.IV.1994, fl., Leme 2359 (HB).

Espécie endêmica do estado do Rio de Janeiro na Floresta Ombrófila Densa (Martinelli et al. 2008; Stehmann et al. 2009). No parque, ocorre na região de Floresta Pluvial Montana, no Soberbo e nas matas em torno do Dedo de Deus. O táxon se caracteriza principalmente pela acentuada heterofilia, sendo as folhas mais externas longoatenuadas, muito mais estreitas que as internas, porte pequeno e presença de estolões. 
2.2. Neoregelia ampullacea (É. Morren) L.B.Sm., Contr. Gray Herb. 104: 78. 1934.

Planta estolonífera, ca. $20 \mathrm{~cm}$ alt. Folhas ca. 7, suberetas e eretas formando uma roseta levemente tubulosa; bainha elíptica, 4,5-7,5 $\times$ 2,5-4,3 cm, roxa, indumento lepidoto em ambas as faces; lâmina linear a oblanceolada, 5,5-16 × 0,7-2 cm, verdes com máculas ou listras purpúreas, indumento lepidoto em ambas as faces, cartácea, ápice arredondado, levemente obtuso, com projeção apiculada ereta, margem serrilhada, acúleos ca. $0,5 \mathrm{~mm}$ compr., espaçados por ca. $4 \mathrm{~mm}$, castanhos. Inflorescência ca. 1,4 cm larg., simples, umbeliforme, pedúnculo ca. $70 \mathrm{~mm}$ compr.. Brácteas Florais oblongas, mais curtas que as sépalas, ápice agudo, margem inteira, membranáceas. Flores ca. 10 , ca. $25 \mathrm{~mm}$ compr., pedicelo ca. $5 \mathrm{~mm}$ compr.; sépalas oblanceoladas, ligeiramente assimétricas, ca. $16 \mathrm{~mm}$ compr., concrescidas por ca. $2 \mathrm{~mm}$, ápice agudo, com pequena projeção apiculada ereta, verdes maculadas de purpúreo; pétalas concrescidas por ca. $2 \mathrm{~mm}$, inteiramente azuis ou somente nas margens; androceu com anteras dorsifixas, filete branco; gineceu com ovário oblongo. Frutos e sementes não vistos.

Material examinado: Petrópolis, Serra da Estrela, 2.X.1967, fl., Pereira 10633 (HB); 15.X.1967, fl., Pereira 10636 (HB).

Espécie endêmica dos estados do Rio de Janeiro e Espírito Santo com ocorrência nas regiões de Floresta Ombrófila Densa (Martinelli et al. 2008; Stehmann et al. 2009). Neste estudo, foi encontrada na Serra da Estrela no município de Petrópolis em Floresta Pluvial Baixo-Montana. O táxon se caracteriza principalmente pela coloração de suas lâminas, verdes com máculas ou listras roxas.

2.3. Neoregelia bragarum (E. Pereira \& L.B.Sm.) Leme, Canistropsis-Bromélias da Mata Atlântica 78. 1998.

Planta epífita, ca. $35 \mathrm{~cm}$ alt. Folhas 10-15, suberetas formando uma roseta infundibuliforme; bainha oblonga, $13-15 \times 7-7,5 \mathrm{~cm}$, na face adaxial roxa na parte distal e verde na proximal, na face abaxial verde com parte proximal castanha, indumento lepidoto denso em ambas as faces; lâmina oblanceolada, $25-27 \times 4,5 \mathrm{~cm}$, verdes com mácula branca no ápice, indumento lepidoto esparso, coriácea, ápice obtuso, com projeção apiculada ereta, margem serrilhada, acúleos 3-4 mm compr., espaçados por ca. $15 \mathrm{~mm}$, castanho-arroxeados. Inflorescência ca. $5,5 \mathrm{~cm}$ larg., simples, umbeliforme, pedúnculo ca. 10 $\mathrm{mm}$ compr.; brácteas do pedúnculo ca. $60 \mathrm{~mm}$ compr., elípticas a estreito-elípticas, ápice agudo, com projeção apiculada ereta, inteira, brancas, cartáceas, indumento lepidoto esparso na face adaxial. Brácteas Florais estreito-elípticas, ca. $40 \mathrm{~mm}$ compr., mais curtas que as sépalas, ápice agudo, sem projeção, margem inteira, cartáceas, não carenadas, brancas, glabras. Flores ca. 14, ca. $75 \mathrm{~mm}$ compr., pedicelo ca. $8 \mathrm{~mm}$ compr.; sépalas elípticas, levemente assimétricas, 20-25 $\mathrm{mm}$ compr., concrescidas por ca. $14 \mathrm{~mm}$, ápice agudo, sem projeção, não cuculadas, verdes; pétalas brancas arroxeadas no ápice; androceu com anteras dorsifixas, filete branco; gineceu com ovário elipsoide. Frutos e sementes não vistos.

Material examinado: Teresópolis, Parque Nacional da Serra dos Órgãos (PARNASO), trilha para Pedra do Sino, 8.I.2011, fl., Moura 1000 (R).

Espécie endêmica do estado do Rio de Janeiro na Floresta Ombrófila Densa e em Formações Campestres (Martinelli et al. 2008; Stehmann et al. 2009). No parque foi encontrada na trilha para a Pedra do Sino em Floresta Pluvial Montana. O exemplar citado é o primeiro registro da espécie para o parque. O táxon se caracteriza principalmente pelas grandes dimensões de suas flores e acúleos.

2.4. Neoregelia carolinae (Beer) L.B. Sm., Contr. Gray Herb. 124: 9. 1939.

Fig. $1 b$

Planta epífita, crescendo por meio de brotos laterais basais, $40-60 \mathrm{~cm}$ alt. Folhas ca. 20, suberetas formando uma roseta infundibuliforme; bainha elíptica, 6-12 ×3-13 cm, branca, indumento lepidoto denso em ambas as faces; lâmina oblanceolada, 1-31 × 1-7 cm, verdes, sendo as internas vermelhas ou róseas na base durante a floração, indumento lepidoto esparso em ambas as faces, cartácea, ápice obtuso, com projeção apiculada ereta, margem serrilhada, acúleos 1-2 mm compr., espaçados por ca. $3 \mathrm{~mm}$, verdecastanhos. Inflorescência ca. $5 \mathrm{~cm}$ larg., simples, umbeliforme a capituliforme, pedúnculo ca. 15 $\mathrm{mm}$; brácteas do pedúnculo $15-45 \mathrm{~mm}$ compr., ovais a estreito-ovais, ápice agudo, com pequena projeção apiculada ereta, inteiras, verdes-claras, cartáceas, indumento lepidoto esparso na face adaxial. Brácteas Florais lanceoladas, 30-45 mm, um pouco mais curtas que as sépalas, ápice obtuso, sem projeção, levemente cuculadas, margem inteira, cartáceas, não carenadas, verdes, glabras. Flores ca. 20, ca. $40 \mathrm{~mm}$ compr., pedicelo ca. $8 \mathrm{~mm}$ compr.; sépalas obovadas, assimétricas, 20-24 mm 
compr., concrescidas por ca. $5 \mathrm{~mm}$, ápice obtuso, sem projeção, verdes; pétalas oblanceoladas, 35-42 $\mathrm{mm}$ compr., concrescidas por ca. $15 \mathrm{~mm}$, brancas com ápice azul, ápice agudo; androceu com anteras brancas, ca. $20 \mathrm{~mm}$ compr.; androceu incluso na corola com estames radiais em torno do estilete, filetes ca. 17-20 mm, adnatos as pétalas, brancos, anteras dorsifixas; gineceu com ovário elipsoide. Frutos bacáceos com cálice persistente, verdes alvacentos, ca. $35 \mathrm{~mm}$ compr..

Material selecionado: Guapimirim, Granja Monte Olivete, trilha das andorinhas, $350 \mathrm{~m}$, 18.I.1995, fr., Braga 1766 (RB); 20.XII.1995, fl., Braga 3151 (RB). Magé, Santo Aleixo, 8.IX.1968, fl., Pereira 10731 (HB); 19.X.2010, fl., Moura 980 (R); 19.X.2010, fl., Moura 982 (R); 31.V.2011, fr., Costa 921 (R). Piabetá, PARNASO, Trilha da Cachoeira Grande, 27.II.2012, fl., Gonçalves 49 (R). Petrópolis, old road up the Serra to Petrópolis, 10.IV.1952, Smith 6458 (NY); Serra da Estrela, 12.III.1967, fr., Pereira 10563 (HB); 18.II.1978, fl., Penna 4 (HB); Trilha do Cachambu Grande, 15.III.2011, fr., Uribbe 9 (R). Serra dos Órgãos, Lutzelburg 20115 (M); Vidal II-1933(952) (R). Teresópolis, Barreira, 10.XII.1948, fl., Duarte 1621 (RB); Serra dos Órgãos, 25.X.1956, fr., Vidal II-1248(952) (R); 25.X.1956, fr., Vidal II-1626(952) (R); 25.X.1956, fr., Vidal II1670(952) (R).

Espécie endêmica do Rio de Janeiro e do Espírito Santo habita a Floresta Ombrófila Densa e Restingas (Martinelli et al. 2008; Stehmann et al. 2009). É a espécie mais frequente do gênero formando grandes populações no interior da Floresta Pluvial Baixo-Montana e Floresta Pluvial Montana em todas as áreas do parque. O táxon se caracteriza principalmente pela coloração das folhas internas da roseta, vermelhas ou róseas.

\subsection{Neoregelia compacta (Mez) L.B. Sm., Contr.} Gray Herb. 124: 9. $1939 . \quad$ Fig. 1c

Planta epífita, estolonífera, ca. $26 \mathrm{~cm}$ alt. Folhas 10-20, suberetas, formando roseta infundibuliforme; bainha elíptica a oval, 8-13 $\times$ 6-8 cm, branca, indumento lepidoto denso em ambas as faces; lâmina linear, 6,5-32 × 2,5-4 cm, verde, sendo as internas inteira ou parcialmente vermelhas durante a floração, indumento lepidoto em ambas as faces, cartácea, ápice vermelho levemente emarginado, com leve projeção apiculada ereta, margem inteira. Inflorescência ca. $3 \mathrm{~cm}$ de larg., simples, umbeliforme, pedúnculo ca. $30 \mathrm{~mm}$ compr.; brácteas do pedúnculo 20-55 $\mathrm{mm}$, mais longas que as sépalas, ovais, ápice emarginado, com pequena projeção apiculada ereta, inteiras, membranáceas, indumento lepidoto esparso em ambas as faces. Brácteas Florais triangulares, ca. $45 \mathrm{~mm}$ compr., mais curtas que as sépalas, ápice agudo, sem projeção, margem inteira, membranáceas, não carenadas, glabras. Flores ca. 6, ca. $50 \mathrm{~mm}$ compr., pedicelo ca. 8 mm compr.; sépalas oblanceoladas, assimétricas, ca. $32 \mathrm{~mm}$ compr., concrescidas por ca. $5 \mathrm{~mm}$, ápice agudo, sem projeção, levemente cuculadas, vermelho-rosadas; pétalas linear-triangulares, ca. $25 \mathrm{~mm}$ compr., ápice agudo; androceu com anteras dorsifixas, anteras e filetes brancos; gineceu com ovário oblongo. Frutos e sementes não vistos.

Material selecionado: Teresópolis, Serra dos Órgãos, 25.X.1956, fl., Vidal II-2596(952) (R); 25.X.1956, fl., Vidal II-2616(952) (R); 25.X.1956, fl., Vidal II2586(952) (R); 11.VII.1967, Pereira 10604 (HB).

Espécie endêmica do estado do Rio de Janeiro e Espírito Santo, ocorrendo na Floresta Ombrófila Densa e Restinga (Martinelli et al. 2008; Stehmann et al. 2009). No Parque o táxon ocorre em Teresópolis sem localidade específica. Nas últimas expedições, não foi recoletada, seu último registro foi feito há mais de 40 anos na região. $\mathrm{O}$ táxon se caracteriza principalmente pela ausência de acúleos e as folhas internas da roseta vermelho-rosadas.

\subsection{Neoregelia concentrica (Vell.) L.B.Sm., Contr.} Gray Herb. 104: 78. 1934.

Fig. 1d

Planta epífita, crescendo por meio de rizomas, 20-40 cm altura. Folhas 7-30, suberetas, formando roseta infundibuliforme; bainha elíptica, 10-17 $\times$ 4,6-12 cm, branca, indumento lepidoto em ambas as faces; lâmina triangular, 7-93 × 3,7-10 cm, verdes, sendo as internas inteira ou parcialmente lilás-arroxeadas, indumento lepidoto em ambas as faces, coriácea, ápice emarginado e obtuso, com projeção apiculada ereta, margem serrilhada, acúleos 3-5 mm, espaçados por 5-10 $\mathrm{mm}$, nigrescentes. Inflorescência 5-9 cm larg., simples, umbeliforme e capituliforme, pedúnculo 60-85 mm compr.; brácteas do pedúnculo 35-60 mm, ovais a estreito-ovais, ápice agudo, com projeção apiculada ereta, inteira, verde-pálidas, cartáceas, indumento lepidoto em ambas as faces. Brácteas Florais lanceoladas, ca. $47 \mathrm{~mm}$ compr., mais curtas que as sépalas, ápice agudo, sem projeção, margem inteira, cartáceas, não carenadas, verdes, indumento lepidoto esparso. Flores ca. 50-100, ca. $40 \mathrm{~mm}$ compr., pedicelo ca. $25 \mathrm{~mm}$ compr.; sépalas ovais, levemente assimétricas, ca. 19 mm compr., concrescidas por 3,5 mm, ápice agudo, projeção apiculada, verdes; pétalas estreito-triangulares, ca. 
$17 \mathrm{~mm}$ compr., concrescidas por ca. $7 \mathrm{~mm}$, brancas com ápice azul-lilás, ápice agudo; androceu com anteras brancas, ca. $10 \mathrm{~mm}$ compr.; gineceu com ovário elipsoide. Frutos bacáceos com cálice persistente, $6 \times 1 \mathrm{~cm}$; sementes fusiformes ca. 1,9 $\times 0,8 \mathrm{~mm}$.

Material selecionado: Serra dos Órgãos, XII.1892, fl., Ule 1985 (R). Magé: Santo Aleixo, Cachoeira Grande, 19.X.2010, fl., Moura 986 (R). Petrópolis: old road up the Serra to Petrópolis, 10.IV.1952, Smith 6492 (NY); Serra da Estrela, 1.I.1968, f1., Pereira 10660 (HB); leito da antiga Estrada de Ferro, meio da serra, $400 \mathrm{msm}$, 29.III.1977, fr., Martinelli 1571 (RB); Parque Nacional da Serra dos Órgãos, estrada velha para Petrópolis, 2.IV.2013, fr., Kessous 50 (R). Teresópolis, Barreira, 9.XII.1948, fr., Duarte 1591 (RB); Parque Nacional da Serra dos Órgãos, III.1952, fr., Vidal II-1254 (R); Serra dos Órgãos, 25.X.1956, Vidal II-2433(952) (R); Parque Nacional da Serra dos Órgãos, sede, 4.XII.1966, fr., Strang 725 \& Castellanos 25.719 (HB); caminho para a Pedra do Sino, 1.450 msm, 27.IV.1977, fr., Martinelli et al. 1716 (RB); Parque Nacional da Serra dos Órgãos, caminho para a Pedra do Sino, próximo ao abrigo 1, 24.V.1987, fr., Fontoura 195 (RB); Parque Nacional da Serra dos Órgãos, 12.VI.1997, fr., Moura 57 (R); Parque Nacional da Serra dos Órgãos, 27.IV.2007, fl., Vargens 11 (R); PARNASO, começo da Trilha Mozart Catão, 16.VII.2012, fr., Kessous 18 (R); Parque Nacional da Serra dos Órgãos, Bosque Santa Helena, 25.XI.2012, fl., Kessous 44 (R).

Espécie endêmica do Rio de Janeiro ocorrendo na Restinga e na Floresta Ombrófila Densa. Espécie frequentemente encontrada no parque em regiões de fácil acesso com populações homogêneas, que se estendem da Floresta Pluvial Baixo-Montana até a Floresta Pluvial Montana. Dentro do gênero, uma das mais frequentes no parque e com grande número de coletas. Apresenta distribuição em todos os municípios que delimitam a UC. O táxon se caracteriza principalmente por suas folhas internas lilás-arroxeadas, lâminas largas com máculas irregulares roxas, roseta aberta e acúleos grandes e nigrescentes.

2.7. Neoregelia coriacea (Antoine) L.B.Sm., Smithsonian Misc. Collect. 126(1): 27. 1955.

Planta epífita, crescendo por meio de rizomas, 17-40 cm. Folhas ca. 8, suberetas, formando roseta infundibuliforme; bainha elíptica a oval, 9-12 × 5,5-8,5 cm, branca, indumento lepidoto em ambas as faces; lâmina linear a lanceolada, 11-40 × 3-4,5 cm, verde, sendo as internas lilases-arroxeadas, coriácea, ápice obtuso, com projeção apiculada ereta, margem serrilhada, acúleos 1,5 mm, espaçados por ca.
$7 \mathrm{~mm}$, nigrescentes. Inflorescência 3,5-9 cm larg., simples, umbeliforme, pedúnculo 55-60 $\mathrm{mm}$; brácteas do pedúnculo $30-40 \mathrm{~mm}$, ovais a triangulares, ápice agudo, com projeção apiculada ereta, inteiras, cartáceas, indumento lepidoto em ambas as faces. Brácteas Florais lineares, 30-35 mm compr., um pouco mais curtas que as sépalas, ápice agudo, sem projeção, não cuculadas, margem inteira, membranáceas, não carenadas, indumento lepidoto esparso. Flores ca. 40, ca. 45 mm compr., pedicelo ca. $17 \mathrm{~mm}$ compr.; sépalas obovadas, assimétricas, ca. $22 \mathrm{~mm}$ compr., concrescidas por ca. $1 \mathrm{~mm}$, ápice agudo, projeção apiculada, não cuculadas, verdes; androceu com anteras dorsifixas; gineceu com ovário oblongo-elipsoide. Frutos e sementes não vistos.

Material selecionado: Magé, Parque Nacional da Serra dos Órgãos, Travessia Inhomirim x Petrópolis, 2.IV.2013, fr., Kessous 47 (R); 2.IV.2013, fl. pass., Kessous 48 (R); 2.IV.2013, fl. pass., Kessous 49 (R). Petrópolis, Serra da Estrela, BR-135, 2.X.1967, fl. pass., Pereira 10628 (HB); Pereira (HB52495).

Endêmica do estado do Rio de Janeiro na Floresta Ombrófila Densa. No parque tem ocorrência restrita a Petrópolis, na Região da Serra da Estrela, em região de Floresta Pluvial Baixo-Montana (Martinelli et al. 2008; Stehmann et al. 2009). O táxon é morfologicamente afim de $N$. concentrica, no entanto, distingue-se, principalmente pelos acúleos e pedicelos menores.

2.8. Neoregelia dungsiana E. Pereira, Bradea 1(25): 276. 1972.

Planta epífita, estolonífera, ca. $20 \mathrm{~cm}$ alt.. Folhas ca. 7, suberetas, formando roseta infundibuliforme; bainha $7 \times 2,5 \mathrm{~cm}$ arroxeada, indumento lepidoto denso em ambas as faces; lâmina linear a lanceolada, 15-18 × 3-3,5 cm, verdes, indumento escamoso branco, cartácea, ápice obtuso, com projeção apiculada ereta, margem serrilhada, acúleos ca. $1 \mathrm{~mm}$ compr., espaçados por 10-20 mm, nigrescentes. Inflorescência ca. 3,5 cm larg., simples, umbeliforme, pedúnculo ca. $60 \mathrm{~mm}$ compr.; brácteas do pedúnculo ca. 20 mm compr., triangulares, ápice agudo, com projeção apiculada ereta, inteira, verde-pálidas, membranáceas, indumento lepidoto em ambas as faces. Brácteas Florais lanceoladas, 20-22 $\mathrm{mm}$ compr., igualando às sépalas, ápice agudo, sem projeção, não cuculadas, margem inteira, membranáceas, não carenadas, verdes, indumento lepidoto esparso. Flores ca. 25, ca. 40 mm compr., pedicelo 3-4 mm compr.; sépalas estreito-ovais a 
lanceoladas, ligeiramente assimétricas, ca. $13 \mathrm{~mm}$ compr., concrescidas por ca. $1 \mathrm{~mm}$, ápice agudo, projeção apiculada, não cuculadas, verdes; pétalas brancas com ápice lilás; androceu com anteras dorsifixas; gineceu com ovário elipsoide. Frutos e sementes não vistos.

Material examinado: Petrópolis, primeiro distrito, Meio da Serra, Serra da Estrela, leito da antiga estrada de ferro, 750 m.s.m., 9.III.1978, fl., Martinelli 4047 (RB).

Espécie endêmica do Espírito Santo e Rio de Janeiro. Ocorre na Floresta Ombrófila Densa (Martinelli et al. 2008; Stehmann et al. 2009). Encontrada na região da Serra da Estrela em Petrópolis, com apenas um registro na região, na Floresta Pluvial Baixo-Montana. O táxon não foi recoletado no âmbito do projeto. $\mathrm{O}$ táxon caracteriza-se principalmente pela pouca quantidade de folhas, presença de estolões e bainha foliar estreita.

\subsection{Neoregelia leucophoea (Baker) L.B.Sm.} Contr. Gray Herb. 124: 9. 1939.

Planta terrícola, estolonífera. Folhas suberetas, formando uma roseta infundibuliforme; bainha elíptica, 14-15 × 9-9,5 cm, verde-escuracastanha, indumento lepidoto denso em ambas as faces; lâmina oblonga, alargada em direção a base, $19-26 \times 5,5-6,5 \mathrm{~cm}$, verde-clara com manchas verde-escuras e purpúreas, indumento lepidoto em ambas as faces, coriácea, ápice arredondado, castanho com os últimos $3 \mathrm{~cm}$ agudos e decíduos, sem projeção, margem serrilhada, acúleos ca. $1 \mathrm{~mm}$ compr., espaçados por $4-12 \mathrm{~mm}$, verdeclaros. Inflorescência ca. 7,5 cm larg., simples, capituliforme, pedúnculo ca. $30 \mathrm{~mm}$ compr.; brácteas do pedúnculo $50-75 \mathrm{~mm}$ compr., ovais, ápice agudo, com projeção apiculada ereta, inteira, brancas, membranáceas, indumento lepidoto em ambas as faces. Brácteas Florais lanceoladas, ca. $55 \mathrm{~mm}$ compr., mais curtas que as sépalas, ápice agudo, sem projeção, não cuculadas, margem inteira, membranáceas, não carenadas, vináceas, indumento lepidoto esparso. Flores ca. 30, ca. $75 \mathrm{~mm}$ compr., pedicelo ca. $25 \mathrm{~mm}$ compr.; sépalas elípticas, assimétricas, ca. $27 \mathrm{~mm}$ compr., concrescidas por ca. $2 \mathrm{~mm}$, ápice agudo, projeção apiculada, não cuculadas, vináceas; pétalas oblanceoladas, ca. $30 \mathrm{~mm}$ compr., concrescidas por ca. $7 \mathrm{~mm}$, brancas, ápice arredondado; androceu com anteras levemente amareladas, ca. $10 \mathrm{~mm}$ compr.; gineceu com ovário elíptico. Frutos bacáceos, oblongos, brancos, ca. $20 \times$ $10-11 \mathrm{~mm}$.
Material examinado: Guapimirim, PARNASO, Trilha da Boca do Peixe, 23K0705064 UTM 7514213, 1.166 m.s.m., 12.IV.2012, fl., Gonçalves 82 (R).

A espécie ocorre na Floresta Ombrófila Densa e é endêmica do estado do Rio de Janeiro (Martinelli et al. 2008; Stehmann et al. 2009). No parque ocorre na trilha para a Boca do Peixe, em Guapimirim, na região de Floresta Pluvial Montana. Espécie com apenas uma coleta registrada para o parque. O material do PARNASO Leme 1699, citado em Leme (1998) não foi encontrado no herbário do Jardim Botânico do Rio de Janeiro. O exemplar citado é o primeiro registro da espécie para o parque. $\mathrm{O}$ táxon caracteriza-se principalmente pelo seu grande porte e por suas pétalas brancas.

2.10. Neoregelia lymaniana $\mathrm{R}$. Braga \& D. Sucre, Rev. Brasil. Biol. 34(4): 491. 1974.

Planta epífita e saxícola, crescendo por meio de brotos laterais entre as folhas. Folhas suberetas, formando roseta infundibuliforme; bainha largoelíptica a obovada, $11,5-14 \times 7-9,5 \mathrm{~cm}$, verde esbranquiçada, indumento lepidoto denso em ambas as faces; lâmina oblanceolada, 6-44 × 2,1-4,5 $\mathrm{cm}$, verdes com faixas liláses na base, indumento lepidoto em ambas as faces, cartáceas, ápice agudo, com projeção apiculada ereta, margem esparsamente serrilhada, acúleos ca. 0,5 mm compr., espaçados por ca. $13 \mathrm{~mm}$, nigrescentes. Inflorescência ca. 5,7 $\mathrm{cm}$ larg., composta, corimbiforme, pedúnculo ca. $7 \mathrm{~cm}$ compr.; brácteas do pedúnculo $35-50 \mathrm{~mm}$ compr., triangulares, ápice agudo, com projeção apiculada ereta, serrilhadas, membranáceas, indumento lepidoto esparso em ambas as faces. Brácteas Florais estreito-triangulares, ca. $45 \mathrm{~mm}$ compr., semelhantes às sépalas, ápice agudo, com projeção apiculada ereta, não cuculadas, margem serrilhada, membranáceas, não carenadas, avermelhadas, indumento lepidoto esparso. Flores ca. 20 , ca. $40 \mathrm{~mm}$ compr., pedicelo ca. $10 \mathrm{~mm}$ compr.; sépalas ovais, ligeiramente assimétricas, 21-28 mm compr., concrescidas por ca. $3 \mathrm{~mm}$, ápice agudo, projeção apiculada, não cuculadas, avermelhadas; pétalas azuis no ápice; androceu com anteras dorsifixas; gineceu com ovário ovoide. Frutos e sementes não vistos.

Material selecionado: Petrópolis, Serra da Estrela, 5.XII.1967, fl., Pereira 10645 (HB); estrada ItaipavaTeresópolis, Km 13, X.1968, fl., Braga 32 (RB); caminho para o Pico do Açú, 21.VI.1986, fl., Leme 929 (RB); Parque Nacional da Serra dos Órgãos, Vale do Rio Jacó, IV.2011, fl., Costa 911 (R); IV.2011, fl., Costa 919 (R). 
Espécie ocorrente no Rio de Janeiro, Minas Gerais e Espírito Santo, na Floresta Ombrófila Densa e na Floresta Estacional Semi-decidual (Martinelli et al. 2008; Stehmann et al. 2009). Encontrada em Petrópolis e Teresópolis na região de limite entre Floresta Pluvial Baixo-Montana e Floresta Pluvial Montana. A espécie foi descrita para região da atual BR-495, ou estrada ItaipavaTeresópolis pela coleta de Ruby Braga em 1968. Outra expedição foi feita a região, porém não foi recoletada. O táxon caracteriza-se principalmente pela sua inflorescência composta, vermelha e brácteas serrilhadas.

\subsection{Neoregelia macahensis (Ule) L.B.Sm. Contr.} Gray Herb. 124: 9. 1939.

Planta crescendo por meio de rizomas, ca. $24 \mathrm{~cm}$ alt.. Folhas ca. 8, suberetas, formando roseta infundibuliforme; bainha elíptica, 10-13,5 $\times$ 9-9,5 cm, avermelhada, indumento lepidoto denso em ambas as faces; lâmina oblanceolada, 10-36 × 4,5-5,5 cm, verde com ápice vermelho, indumento lepidoto em ambas as faces, coriácea, ápice ligeiramente emarginado, com projeção apiculada ereta, margem serrilhada, acúleos 0,5-1 mm compr., espaçados por ca. $10 \mathrm{~mm}$, atropurpúreos. Inflorescência ca. 4,7 cm larg., simples, pedúnculo ca. $65 \mathrm{~mm}$ compr.; brácteas do pedúnculo ca. $36 \mathrm{~mm}$ compr., triangulares, ápice agudo, com projeção apiculada ereta, inteiras, verdes, membranáceas, indumento lepidoto esparso em ambas as faces. Brácteas Florais lanceoladas, ca. $28 \mathrm{~mm}$ compr., mais curtas que as sépalas, ápice agudo, sem projeção, não cuculadas, margem inteira, membranáceas, não carenadas, verdes, indumento lepidoto esparso. Flores ca. 24, ca. 45 $\mathrm{mm}$ compr., pedicelo ca. $18 \mathrm{~mm}$ compr.; sépalas ovais, assimétricas, ca. $19 \mathrm{~mm}$, concrescidas por ca. $1 \mathrm{~mm}$, ápice agudo, projeção apiculada, não cuculadas, verdes; pétalas brancas com ápice azul androceu com anteras dorsifixas; gineceu com ovário oblongo. Frutos e sementes não vistos.

Material examinado: Petrópolis, Serra da Estrela, 1.I.1968, fl., Pereira 10659 (HB).

Espécie endêmica do Rio de Janeiro na Floresta Ombrófila Densa (Martinelli et al. 2008; Stehmann et al. 2009). No parque esta espécie se limita à região de Petrópolis, com apenas uma coleta, na Serra da Estrela, na Floresta Pluvial Baixo-Montana. Apesar das novas expedições terem sido feitas na Serra da Estrela, essa espécie não foi recoletada. O táxon caracteriza-se principalmente pelas lâminas verdes concolores.
2.12. Neoregelia tristis (Beer) L.B.Sm., Proc. Amer. Acad. 70: 153. $1935 . \quad$ Fig. 1e Planta saxícola, crescendo por meio de rizomas, ca. $30 \mathrm{~cm}$ alt.. Folhas $10-12$, suberetas, formando roseta infundibuliforme; bainha elíptica, $6,5-11 \times 2,7-6 \mathrm{~cm}$, verde maculada de roxo, indumento lepidoto em ambas as faces; lâmina linear ou estreito-oblonga, 5-35 × 1,5-2,5 cm, verde maculada de purpúreo na base, indumento lepidoto em ambas as faces, cartácea, ápice agudo, com projeção apiculada ereta, margem serrilhada, acúleos ca. 0,5-1 mm compr., espaçados por até 33 $\mathrm{mm}$, verde-nigrescentes. Inflorescência ca. $5 \mathrm{~cm}$ larg., simples, umbeliforme, pedúnculo ca. $7 \mathrm{~cm}$ compr.; brácteas do pedúnculo 20-30 mm compr., estreito-ovais a ovais, ápice agudo e arredondado, com projeção apiculada ereta, inteiras, alvas, vináceas em direção ao ápice, membranáceas, indumento lepidoto esparso em ambas as faces. Brácteas Florais estreito-oblongas, ca. $20 \mathrm{~mm}$ compr., mais curtas que as sépalas, ápice levemente agudo, sem projeção, não cuculadas, margem inteira, membranáceas, não carenadas, vináceas, indumento lepidoto esparso. Flores ca. 30, ca. 40 $\mathrm{mm}$ compr., pedicelo ca. $8 \mathrm{~mm}$ compr.; sépalas ovais, ligeiramente assimétricas, $13-15 \mathrm{~mm}$, concrescidas por ca. $3 \mathrm{~mm}$, ápice agudo, projeção apiculada, levemente cuculadas, vináceas; pétalas oblanceoladas, ca. $21 \mathrm{~mm}$ compr., concrescidas por ca. $10 \mathrm{~mm}$, brancas, roxas em direção à base, ápice agudo recurvado; androceu com anteras brancas, ca. $15 \mathrm{~mm}$ compr.; gineceu com ovário elipsoide. Frutos bacáceos com cálice persistente, ca. $10 \mathrm{~mm}$ compr.; sementes ovóides, 0,45 × 0,2 mm.

Material selecionado: Petrópolis, Serra da Estrela, 25.II.1917, fl., Diogo 717 (R); meio da Serra, 24.IV.1967, fl., Pereira 10580 (HB); Estrada Velha, 10.XII.1982, fl., Ivo 24 (HB); PARNASO, Vale do Rio Itamaraty, 1.600 m.s.m., 12.III.2008, fl., Aximoff 45 (RB). Teresópolis, Parque Nacional da Serra dos Órgãos, caminho para Pedra do Sino, ca. 1.450 m.s.m., 27.IV.1977, fl., Martinelli 1718 (RB); Parque Nacional da Serra dos Órgãos, Rio Beija-flor, 1.100-1.200 m.s.m., 20.X.1977, fl., Martinelli 3305 (RB); Parque Nacional da Serra dos Órgãos, caminho para o Nariz do Frade, mata úmida, 24.V.1987, fr., Fontoura 149 (RB); trilha para o Rancho Frio, 22.I.2010, fl., Gomes-da-Silva 65 \& Costa (R); Travessia da Neblina, 14.II.2012, fl., Gonçalves 42 (R); Cascata dos Amores, 16.II.2012, fl., Gonçalves 45 (R); trilha do Mirante do Cartão Postal, 20.X.2010, fl., Moura 981 (R); estrada de dentro do PARNASO, próximo à placa de número 2.800 m, 11.V.2012, fr. Kessous 2 (R). Endêmica do Espírito Santo e do Rio de Janeiro na Floresta Ombrófila Densa (Martinelli 
et al. 2008; Stehmann et al. 2009). No parque, a espécie ocorre em Petrópolis e Teresópolis se estendendo da Floresta Pluvial Baixo-Montana até a Floresta Pluvial Montana. O táxon é caracterizado pelo seu hábito saxícola, lâminas estreitas e inflorescência com brácteas e sépalas vináceas, e pétalas alvas.

\subsection{Neoregelia sp.}

Fig. 1f

Planta epífita, ciófita, crescendo por meio de rizomas. Folhas ca. 9, suberetas, formando roseta infundibuliforme; bainha obovada a oblonga, $14-16 \times 7,9-8,2 \mathrm{~cm}$, roxas maculadas de verde, indumento lepidoto denso em ambas as faces; lâmina linear ou estreito-oblonga, 10-27 × 4,5-5 $\mathrm{cm}$, verde com máculas purpúreas em direção a base e ápice roxo, indumento escamoso em ambas as faces, cartácea, ápice obtuso, com projeção apiculada ereta, margem serrilhada, acúleos 1-5 mm compr., espaçados por 5-20 mm, nigrescentes. Inflorescência ca. 7,5 cm larg., capituliforme; pedúnculo branco, ca. $55 \mathrm{~mm}$ compr.; brácteas do pedúnculo $25-45 \mathrm{~mm}$ compr., ovais, ápice agudo, com projeção apiculada ereta, inteira, membranáceas, indumento lepidoto em ambas as faces. Brácteas Florais estreito-oblongas, ca. $37 \mathrm{~mm}$ compr., mais curtas que as sépalas, ápice obtuso, sem projeção, levemente cuculado, margem inteira, membranáceas, não carenadas, castanhas, pálidas em direção à base, indumento lepidoto esparso. Flores ca. 100, ca. $55 \mathrm{~mm}$ compr., pedicelo 5-15 mm compr.; sépalas obovadas, assimétricas, ca. $22 \mathrm{~mm}$ compr., concrescidas por ca. $2 \mathrm{~mm}$, ápice agudo, projeção apiculada, não cuculadas, não carenadas, vináceo-esverdeadas em direção ao ápice; pétalas oblanceoladas, ca. $40 \mathrm{~mm}$ compr., brancas com ápice lilás, ápice agudo; androceu branco, estames ca. $20 \mathrm{~mm}$ compr., anteras dorsifixas; gineceu com ovário oblongo. Frutos e sementes não vistos.

Material examinado: Teresópolis, PARNASO, Trilha do Sino, 23K 0705008 UTM 7516212, 1.311 m.s.m., 19.III.2012, fl., Gonçalves 69 (R).

A espécie ocorre na Floresta Ombrófila Densa, na região de Floresta Pluvial Montana, endêmica do estado do Rio de Janeiro (Martinelli et al. 2008; Stehmann et al. 2009). Ocorre no início da trilha para a Pedra do Sino. Apesar de ser uma região de fácil acesso e muito explorada, não foi encontrada novamente. $\mathrm{O}$ indivíduo apresenta características morfologicamente similares a outras espécies dentro do parque. Apresenta número de flores, tamanho da inflorescência e pedicelos semelhantes a $N$. concentrica e coloração da bainha e sépala semelhantes a $N$. tristis. Ambas estas espécies ocorrem nesta região do parque. Este indivíduo caracteriza-se principalmente pela roseta aberta, largura da lâmina, grande quantidade de flores e sépalas vináceas.

\section{Wittrockia Lindm.}

Wittrockia possui sete espécies endêmicas do Brasil (BFG 2015). Ocorre predominantemente no Domínio Atlântico, sobretudo em ecossistemas florestais (Florestas Estacionais Semideciduais e Florestas Ombrófilas) com seis espécies endêmicas deste domínio (Martinelli et al. 2008). Uma exceção é Wittrockia flavipetala (Wand.) Leme \& H.Luther que é endêmica do domínio da Caatinga e do Cerrado (BFG 2015). No PARNASO está representado por duas espécies, das quais $W$. cyathiformis, presente nas matas nebulares e regiões mais altas do parque e $W$. gigantea, presente apenas na região da Cascatinha em Petrópolis.

\section{Chave de identificação das espécies de Wittrockia no PARNASO}

1. Planta terrícola; pedúnculo $23-54,5 \mathrm{~cm}$ compr. excedendo a roseta; sépalas ca. $20 \mathrm{~mm}$ compr.; pétalas ca. $15 \mathrm{~mm}$ compr. 3.1. Wittrockia cyathiformis

1'. Planta epífita; pedúnculo 9-11,5 cm compr. incluso na roseta; sépalas ca. $30 \mathrm{~mm}$ compr.; pétalas ca. 40 mm compr. 3.2. Wittrockia gigantea

3.1. Wittrockia cyathiformis (Vell.) Leme Canistrum: Bromélias da Mata Atlântica. 67, 1997.

Fig. $1 \mathrm{~g}$

Planta terrícola, $33-58 \mathrm{~cm}$ alt. quando florida; roseta infundibuliforme. Folhas suberetas, espiraladas; bainha 10,5-20 × 4,6-10 cm, oblonga a elíptica, alvacenta, indumento lepidoto denso em ambas as faces; lâmina 11,5-63,3 × 4,7-5,6 cm, oblonga a sublinear, serrilhada, verde concolor, indumento lepidoto em ambas as faces, esparso na face adaxial, ápice agudo. Inflorescência composta, subumbeliforme, densa, sobressaindo 
à roseta, 5-6,5 × 3,5-10 cm; pedúnculo 23,3-54,5 compr. $\times 0,3-0,45 \mathrm{~cm}$ diâmetro, ereto a subereto, glabro; brácteas do pedúnculo 2-2,9 × 4-8,2 $\mathrm{cm}$, elípticas, serreadas, 7,5-22,7 cm, congestas, vermelhas, próximas à parte fértil da inflorescência, ápice apiculado a acuminado, vermelhas, glabras; brácteas primárias 4,3-6,4 × 1,4-2,5 cm, oblongas a elípticas, margem serrada, ápice agudo a acuminado, vermelhas, glabras, reflexas, mais longas que os pedúnculos; ramos suberetos. Brácteas Florais 2,4 × 0,7 cm, oblongas a elípticas, margem inteira, ápice acuminado, verde-alvacentas, glabras, mais longas que as sépalas. Flores sésseis, suberetas; sépalas $21 \times 2,5-3 \mathrm{~mm}$, subsimétricas, lanceoladas, carenadas, ápice acuminado, amarelas, glabras; pétalas ca. $16 \times 4 \mathrm{~mm}$, obovadas, ápice agudo, eretas, livres, apêndices na base; estames inclusos; ovário trígono. Fruto bacáceo, alvacento. Material examinado: Guapimirim, Parque Nacional da Serra dos Órgãos, próximo ao Museu Martius, 21.X.1977, fr, Martinelli \& Maas 3337 (HB). Petrópolis, Parque Nacional da Serra dos Órgãos, base do Nariz do Frade, 14.III.2012, fl., Gonçalves 65 (R); Agulha do Diabo, 21.II.2009, fl., França \& Moura 41 (R); Cachoeira do Rancho Frio, 23.VIII.1940, fr., Brade $16627(\mathrm{R})$.

Ocorre na Bahia, Minas Gerais, Rio de Janeiro, São Paulo, Paraná e Santa Catarina no domínio da Mata Atlântica (Martinelli et al. 2008; Stehmann et al. 2009). No PARNASO é encontrada em altitudes entre 380 e 2.100 metros na Floresta Ombrófila Densa montana e altomontana. O táxon caracteriza-se principalmente por suas brácteas primárias vermelhas e sua inflorescência excedendo a roseta.

3.2. Wittrockia gigantea (Baker) Leme-Canistrum: Bromélias da Mata Atlântica. 70, 1997. Fig. 1h Planta epífita, 22-27,5 cm alt. Folhas suberetas, formando roseta infundibuliforme; bainha elíptica, 12,5-13 × $7 \mathrm{~cm}$, verde-alvacenta, indumento lepidoto denso em ambas as faces; lâmina linear a sublinear, mais estreita na base, alargando-se em direção ao ápice, 118,5-122,2 $\times 4 \mathrm{~cm}$, verde, indumento lepidoto em ambas as faces, coriácea, ápice agudo, com projeção apiculada ereta, margem serrilhada, acúleos mais densos no terço basal, esparsos em direção ao ápice, 0,47-5,1 mm espaçados no terço basal da lâmina por 1,9-17,6 mm, negros in sicco. Inflorescência 19,5-21,5 × $8 \mathrm{~cm}$, composta, ereta, não embutida na roseta, subumbeliforme, com flores congestas; pedúnculo ereto, glabro,
9-11,5 × 1,3 cm; brácteas do pedúnculo 7,5-22,7 cm compr., congestas, vermelhas, próximas da parte fértil da inflorescência, ápice apiculado a acuminado, vermelhas, glabras; imbricadas, 9,4-13 × 2,3 cm, com base oval e lâmina lineartriangular, ápice obtuso, com projeção apiculada, margem serreada, com apículos mais densos na base, coriáceas, indumento lepidoto em ambas as faces. Fascículos 8-9, suberetos; brácteas primárias 12,4-15,8 cm compr., mais curtas que o pedúnculo, subtriangulares, ápice agudo, projeção apiculada, margem serrilhada, vermelhas na base e verde para o ápice, indumento lepidoto denso em ambas as faces. Brácteas Florais lineares, ca. $46 \mathrm{~mm}$, mais curtas que as sépalas, ápice acuminado, com pequena projeção apiculada ereta, margem inteira, cartácea, não carenadas, amareladas, glabras. Flores 58-76 mm compr., eretas, sésseis; sépalas subovadas, simétricas, 32-37,5 mm compr., livres, ápice acuminado, margem inteira, coriáceas, não carenadas, amareladas, glabras; pétalas estreitoobovadas, ca. $39 \times 12,5 \mathrm{~mm}$, livres, alvas, ápice agudo, glabras, membranáceas; anteras ca. 11,5 mm compr, filetes livres, alvos; gineceu com ovário elipsoide. Frutos elipsoides, ca. 22,6 mm.

Material examinado: Petrópolis, Parque Nacional da Serra dos Órgãos, Cascatinha, III.2012, fr., Schittini 1 (R).

Ocorre no estado de Minas Gerais, Rio de Janeiro e mais raramente em São Paulo, na Floresta Ombrófila Densa (Stehmann et al. 2009). No PARNASO, esta espécie ocorre na Floresta Pluvial Baixo Montana em Guapimirim. Wittrockia gigantea encontra-se protegida em várias unidades de conservação, como o Parque Estadual do Ibitipoca (MG), Parque Estadual da Serra do Brigadeiro (MG), Parque Nacional do Itatiaia (RJ) e Parque Nacional da Serra dos Órgãos. O exemplar citado é o primeiro registro da espécie para o parque. O táxon caracteriza-se principalmente por seu grande porte.

\section{Agradecimentos}

Agradecemos à CAPES, as bolsas de Doutorado concedidas a IMK, BPS e DRC; ao CNPq, a bolsa de Produtividade em pesquisa para AFC e de PIBIC para IMK, e os recursos do Protax. Agradecemos também à CRT (Concessionária Rio-Teresópolis $\mathrm{S} / \mathrm{A}$ ), os recursos de expedições de campo; à bióloga Alessandra Ribeiro e à equipe do projeto Bromeliaceae organensis, o auxílio nas coletas; à equipe do PARNASO, em especial a Cecília C. Faria, e aos monitores, o suporte; ao 
Museu Nacional-UFRJ, o auxílio e infraestrutura; aos curadores dos herbários citados no texto, o acesso aos seus acervos.

\section{Referências}

APG IV (2016) An update of the Angiosperm Phylogeny Group classification for the orders and families of flowering plants: APG IV. Botanical Journal of the Linnean Society 181: 1-20.

Baker JG (1889) Handbook of the Bromeliaceae. George Bell \& Sons, Londres. 243p.

Beer JG (1857) Die Familie der Bromeliaceen. Tendler \& Comp., Wien. 271p.

BFG - The Brazil Flora Group (2018) Brazilian Flora 2020: innovation and collaboration to meet Target 1 of the Global Strategy for Plant Conservation (GSPC). Rodriguésia 69: 1513-1527.

Bouchenak-Khelladi Y, Muasya AM \& Linder HP (2014) A revised evolutionary history of Poales: origins and diversification. Botanical Journal of the Linnean Society 175: 4-16.

Brown GK \& Leme EMC (2000) Dados moleculares em Bromeliaceae. In: Leme EMC (ed.) Nidularium: Bromélias da Mata Atlântica. Salamandra, Rio de Janeiro. Pp. 198-201.

Chase MW, Soltis DE, Soltis PS, Rudall PJ, Fay MF, Hahn WH, Sullivan S, Joseph J, Molvray M, Kores PJ, Givinish TJ, Sytsma KJ \& Pires JC (2000) Higher-level systematics of the monocotyledons: an assessment of 34 current knowledge and a new classification. In: Wilson KL \& Morrison DA (eds.) Monocots: systematics and evolution, Melbourne. Pp. 3-16.

Cronemberger C \& Viveiros-de-Castro E (2007) Ciência e conservação na Serra dos Órgãos. Ed. Instituto Chico Mendes de Conservação da Biodiversidade, Brasília. 296p.

Duvall MR, Clegg MT, Chase MW, Clark WD, Kress WJ, Hills HG, Eguiarte LE, Smith JF, Gaut BS, Zimmer EA \& Learn JrGH (1993) Phylogenetic hypotheses for the monocotyledons constructed from $r b c \mathrm{~L}$ sequence data. Annals of the Missouri Botanical Garden 80: 607-619.

Evans TM, Jabaily RS, de Faria APG, de Sousa LDOF, Wendt T \& Brown GK (2015) Phylogenetic relationships in Bromeliaceae subfamily Bromelioideae based on Chloroplast DNA Sequence Data. Systematic Botany 40: 116-128.

Gaut BS, Muse SV, Clark WD \& Clegg MT (1992) Relative rates of nucleotide substitution at the $r b c \mathrm{~L}$ locus of monocotyledonous plants. Journal of molecular evolution 35: 292-303.

Givnish TJ, Millan KC, Berry PE \& Sytsma KJ (2007) Phylogeny adaptative radiation and historical biogeography of Bromeliaceae inferred from ndhF sequence data. In: Columbus JT, Friar EA, Porter JM, Prince LM \& Simpson MG (eds.) Monocots: comparative biology and evolution - Poales. Rancho Santa Ana Botanic Garden, Claremont. Pp. 3-26.

Givnish TJ, Barfuss MHJ, Van Ee B, Riina R, Schulte K, Horres R, Gonsiska PA, Jabaily RS, Crayn DM, Smith JAC, Winter K, Brown GK, Evans TM, Holst BK, Luther H, Till W, Zizka G, Berry PE \& Sytsma KJ (2011) Phylogeny, adaptive radiation, and historical biogeography in Bromeliaceae: insights from an eight-locus plastid phylogeny. American Journal of Botany 98: 872-895.

Gouda EJ, Butcher D \& Gouda K [continuamente atualizado]. Encyclopaedia of Bromeliads. Version 3.1 (2012) [and more or less continuosly updated since]. Disponível em <http://encyclopedia. florapix.nl/>. Acesso em 23 março 2016.

Heller S, Leme EMC, Schulte K, Benko-Iseppon AM \& Zizka G (2015) Elucidating Phylogenetic Relationships in the Aechmea Alliance: AFLP Analysis of Portea and the Gravisia Complex (Bromeliaceae, Bromelioideae). Systematic Botany 40: 716-725.

Horres R, Zizka G, Kahl G \& Weising K (2000) Molecular phylogenetics of Bromeliaceae: evidence from trnL (UAA) intron sequences of chloroplast genome. Plant Biology 2: 306-315.

Horres R, Schulte K, Weising K \& Zizka G (2007) Systematics of Bromelioideae (Bromeliaceae) Evidence from Molecular and anatomical studies. Aliso 23: 27-43.

IBGE - Instituto Brasileiro de Geografia e Estatística (2012) Manual técnico da vegetação brasileira. Segunda edição revista e ampliada. IBGE, Rio de Janeiro. 271p.

ICMbio (2008) Plano de manejo do Parque Nacional da Serra dos Órgãos, vol. II - anexos. Disponível em <http://www.icmbio.gov.br/portal/images/ stories/imgs-unidades-coservacao/Anexos-PMPARNASO.pdf $>$. Acesso em 14 setembro 2016.

Kessous IM \& Costa AF (2017) Canistropsis (Mez) Leme e Nidularium Lem. (Bromeliaceae: Bromelioideae) no Parque Nacional da Serra dos Órgãos, Rio de Janeiro, Brasil. Rodriguésia 68: 233-244.

Leme EMC (1997) Bromélias da Mata Atlântica Canistrum. Ed. Salamandra, Rio de Janeiro. 107p.

Leme EMC (1998) Bromélias da Mata Atlântica Canistropsis. Ed. Salamandra, Rio de Janeiro. $143 p$.

Leme EMC (2000) Bromélias da Mata Atlântica Nidularium. Ed. Sextante, Rio de Janeiro. 263p.

Luther HE \& Sieff E (1994) De Rebus Bromeliacearum I. Selbyana 15: 9-93.

Luther HE \& Sieff E (1997) De Rebus Bromeliacearum II. Selbyana 18: 103-140.

Luther HE (2001) De Rebus Bromeliacearum III. Selbyana 22: 34-67.

Luther HE \& Rabinowitz L (2010) De Rebus Bromeliacearum IV. Selbyana 30: 147-189. 
Luther HE (2012) An alphabetical list of bromeliad binomials. $13^{\mathrm{a}}$ ed. The Bromeliad Society International, Sarasota. 41p.

Martinelli G, Vieira CM, Gonzalez M, Leitman P, Piratininga A, Costa AF \& Forzza RC (2008) Bromeliaceae da Mata Atlântica Brasileira: lista de espécies, distribuição e conservação. Rodriguésia 59: 209-258.

Martinelli G, Vieira CM, Leitman P, Costa AF \& Forzza RC (2009) Bromeliaceae. In: Stehmann JR, Forzza RC, Salino A, Sobral M, Costa DP \& Kamino LHY (eds.) Plantas da Floresta Atlântica. Instituto de Pesquisas Jardim Botânico do Rio de Janeiro, Rio de Janeiro. Pp. 186-204.

Mez C (1892-4) Bromeliaceae. In: von Martius CFP; Eichler AW \& Urban I (eds.) Flora brasiliensis, München, Wien 3: 173-674.

Mez C (1896) Bromeliaceae. In: Candolle ALPP de \& Candolle ACP.de (eds.) Vol. 9. Monographiae phanerogamarum, Paris. Pp. 1-990.

Mez C (1934-5) Bromeliaceae. In: Engler HGA (ed.) Das Pflanzenreich. Vol. 4. Wilhem Engelmen, Berlin. Pp. 1-667.

Mittermeier RA, Robles-Gil P, Hoffmann M, Pilgrim J, Brooks T, Mittermeier CG, Lamoreux J \& da Fonseca GAB (2004) Hotspots revisited: Earth's biologically richest and most endangered ecoregions. CEMEX, Mexico City. 392p.

MMA - Ministério do Meio Ambiente (2014) Portaria $n^{\circ}$. 443, de 17 de dezembro de 2014 - lista nacional oficial de espécies da flora ameaçadas de extinção. Diário Oficial da União - seção $1, \mathrm{n}^{\circ}$. 245, 18 de dezembro de 2014. Brasília. Pp. 110-121.

Neves B, Uribbe FP, Jacques SSA, Paixão-Souza B, Moura RLD, Barros AAM \& Costa AF (2015) Aechmea e gêneros relacionados (Bromelioideae, Bromeliaceae) no Parque Nacional da Serra dos Órgãos, Rio de Janeiro, Brasil. Rodriguésia 66: 555-570.

Peixoto AL \& Maia LC (2013) Manual de procedimentos para herbários. Editora Universitária da UFPE, Recife. 97p.

Radford AE (1986) Fundamentals of plant systematics. Harper \& Row, New York. 891p.

Rizzini CT (1979) Tratado de Fitogeografia do Brasilaspectos sociológicos e florísticos. Hucitec/Ed. USP, 2, São Paulo. 347p.
Safford HD (1999) Brazilian Páramos I: an introduction to the physical environment and vegetation of the campos de altitude. Journal of Biogeography 26: 693-712.

Safford HD \& Martinelli G (2000) Southeast Brazil. In: Inselbergs: biotic diversity of isolated rock outcrops in Tropical and Temperate regions. Springer, Heidelberg. Pp. 339-389

Santos-Silva F, Venda AKL, Hallbritter HM, Leme EMC, Mantovani A \& Forzza RC (2017) Nestes in chaos: Insights on the relations of the "Nidularioid Complex" and the evolutionary history of Neoregelia. Brittonia: 1-15.

Sass C \& Specht CD (2010) Phylogenetic estimation of the core Bromelioids with emphasis on the genus Aechmea (Bromeliaceae). Molecular Phylogenetics and evolution 55: 559-571.

Scharf U \& Gouda EJ (2008) Bringing Bromeliaceae back to homeland botany. Journal of the Bromeliad Society 58: 123-129.

Schulte K, Barfuss MH \& Zizka G (2009) Phylogeny of Bromelioideae (Bromeliaceae) inferred from nuclear and plastid DNA loci reveals the evolution of the tank habit within the subfamily. Molecular Phylogenetics and Evolution 51: 327-339.

Schulte K, Horres R \& Zizka G (2005) Molecular phylogeny of Bromelioideae and its implications on biogeography and evolution of CAM in the family (Poales, Bromeliaceae). Senckenbergiana biologica 85: 113-125.

Smith LB \& Downs RJ (1979) Bromelioideae. Flora Neotropica Monograph 14: 1493-2142.

Stehmann JR, Forzza RC, Salino A, Sobral M, Costa DP \& Kamino LHY (2009) Plantas da Floresta Atlântica. Instituto de Pesquisas Jardim Botânico do Rio de Janeiro, Rio de Janeiro. 505p.

Terry RG, Brown GK \& Olmstead RG (1997) Examination of subfamilial phylogeny in Bromeliaceae using comparative sequencing of the plastid locus $n d h F$. American Journal of Botany 84: 664-670.

Thiers B [continuamente atualizado] Index Herbariorum: a global directory of public herbaria and associated staff. New York Botanical Garden's Virtual Herbarium. Disponível em $<$ http://sweetgum.nybg. org/science/ih/>. Acesso em 25 março 2016. 